\title{
Precarious Transnationality in Family Relations on the Finnish-Russian Border during the Soviet and Post-Soviet Periods
}

\author{
Olga Davydova-Minguet * and Pirjo Pöllänen (D)
}

check for updates

Citation: Davydova-Minguet, Olga, and Pirjo Pöllänen. 2021. Precarious Transnationality in Family Relations on the Finnish-Russian Border during the Soviet and Post-Soviet Periods. Genealogy 5: 92. https://doi.org/ 10.3390/genealogy5040092

Received: 11 August 2021

Accepted: 15 October 2021

Published: 22 October 2021

Publisher's Note: MDPI stays neutral with regard to jurisdictional claims in published maps and institutional affiliations.

Copyright: (c) 2021 by the authors. Licensee MDPI, Basel, Switzerland. This article is an open access article distributed under the terms and conditions of the Creative Commons Attribution (CC BY) license (https:// creativecommons.org/licenses/by/ $4.0 /)$.
Karelian Institute, University of Eastern Finland, 80100 Joensuu, Finland; pirjo.pollanen@uef.fi

* Correspondence: olga.davydova-minguet@uef.fi

\begin{abstract}
The article develops the view of transnational familyhood as an affect of precarity. Transnationality itself is viewed as being defined by state actors and border regimes which make transnational connections fragile and vulnerable. The precarity is compared here with "the lease that is not in your pocket". The text assembles the authors' ethnographic work in Finnish-Russian border areas from two decades. Using the methodology of narrative ethnography, the study creates a picture of the atmosphere and affects in which transnational familyhood has been kept alive from the early 1920s until today. The historical context of transnational familyhood is divided into four periods: the period of confrontation and wars, 1920s-1940s; the period of friendly cooperation and a selectively open border, 1950s-1980s; the post-Soviet period of a conditionally open border and migration, 1990s-2010s; and the post-Crimean period of rebordering and the securitization of the transnational everyday since 2014. The everyday reality of transnational familyhood is portrayed through the constructed figures of "Aili" and "Vera", who represent women belonging to transnational families from different generations.
\end{abstract}

Keywords: transnational family; precarity; affect; border; Finland; Russia; Karelia

\section{Introduction}

The transnational everyday of Russian-speaking immigrants in Finland has been precarious and vulnerable throughout the Soviet period. After the collapse of the Soviet Union (USSR, Union of Soviet Socialist Republics) transnational connections between populations of bordering Russia and Finland became part of people's everyday lives due to extensive cross-border trade, travelling, tourism and migration. However, the geopolitical tensions, namely the conflict between the "West" and Russia that followed the annexation of Crimea by Russia and the beginning of the war in Eastern Ukraine, have had consequences in Russian-speaking immigrants' lives in Finland as well. This geopolitical change has brought back the sensation of threat and vulnerability to the lives of people who have transnational family and care obligations on the other side of the border. This study contributes to the research of transnational familyhood in the post-Soviet migratory context from the perspective of the Finnish-Russian border (Davydova-Minguet and Pöllänen 2020; Assmuth et al. 2018; Davydova-Minguet and Pöllänen 2017; Siim 2016; Pöllänen 2013; Tiaynen 2013; Zechner 2008; Hyvönen 2007; Saarinen 2007; Zechner 2006).

The conceptual frame of this article is inspired by the discussion of precarization and precarity, which we develop as diachronically intertwined with transnational family relations in the Finnish-Russian border area, spanning several decades from approximately the 1920s until today. Previously, we addressed precarization as a hollowing out of the welfare state, fragmentation of the labour market, and the porosity of societal structures as a whole. As we have stated previously (Pöllänen and Davydova-Minguet 2017, pp. 177-78), "the forms of work, education, family life, sociality and leisure, civic society and politics, and also international relations are shifting from lifetime, stable endeavours towards 
temporary, unstable, uncertain projects and phenomena. Because of these processes, many populations (especially women and migrants) have to face uncertain circumstances not only from an economic point of view, but also as a result of the emotional and functional frames that shape their lives. As an additional consideration, the global geopolitical order has become even more unstable and militant and is now vulnerable to conflicts which develop not only in the 'traditional' locations of the unstable Middle East, but also in post-Soviet areas. This instability creates feelings of precariousness, especially among groups of a population that have had some personal connection to the territories where such conflicts arise."

In this article we are particularly concerned with the affectional dimension of precarization (see e.g., Jokinen and Venäläinen 2015; Åkerblad 2014; Berlant 2011; Adkins and Jokinen 2008). We stretch our thinking in two directions: first, we examine precarity in transnational family relations diachronically, including the Soviet period in our examination. Second, we ponder the influences of post-Soviet transformation on the transnational families that have formed since the early 1990s, after the liberalization of the border regime between Finland and Russia. We ask, what affective and personal dimensions the precarity produced by families' transnationality has had during the Soviet and Post-Soviet periods. We aim at examining these dimensions through contemporary and historical lenses.

The most well-known context of precarization studies is the neoliberal transformation of labour markets and societal structures and institutions (see Berlant 2011; Papadopoulos et al. 2008). However, according to Eeva Jokinen (2020), "precarity is not only an already realized labour market risk, but also something that lies in the potential, people's feeling that something unexpected, unpleasant, or uncontrollable may happen. The French etymology of the word precarity sums this up well: it originally meant 'a lease that is not in your own pocket"' (free translation by authors from original text in Finnish). Precarity in this rendering is an affective state caused by societal institutions, their functions, and transformations. In our case this refers to state borders, border regimes, bordering processes and the unpredictability of the everyday life of those affected by borders and bordering, and the fragility of maintaining transnational family relations that has for decades made the everyday life of transnational families precarious.

When authors (e.g., Jokinen and Venäläinen 2015; Åkerblad 2014; Berlant 2011; Papadopoulos et al. 2008) discuss precarization as a consequence of an institutional change (such as changes in the labour markets), such emotions and conditions as unpredictability, anxiety, uncertainty, and even fear come to the fore. In contrast, we define precarization itself as an affect, which is always a structural, social, and individual combination of experiences, emotions, and feelings. They in turn define bodies, social relations, and possibilities to act in a hierarchical structure in which affects are embedded, and which in turn maintain these structures (Ahmed 2004).

Instead of analysing the porous welfare state or labour market as a context of precarity, we examine borders, border areas, bordering, and border regimes. The border is an institution and mechanism for sorting peoples: defining insiders and outsiders, those who are entitled to cross the border and those who must stay put, and those who make decisions on border governance. Borders inevitably produce inequalities and hierarchies change over time, yet even the "open" border continues to recreate them (Rigo 2009; Brambilla 2015; Paasi 1998). In short, the border is both precarious and affective.

Our study is embedded in the research on transnational family, which in the research literature is connected with the phenomena of globalization, migration, and diaspora (Bryceson and Vuorela 2002; Brah 1998). Transnational families are defined as those who live apart, divided by national borders, but who stay together. Such families create entities that provide a sense of collective wellbeing, community, and familyhood, even across national borders (Bryceson and Vuorela 2002). Families' practices of creation and maintaining familyhood such as "relativizing" and "frontiering" include transnational care and maintaining emotional and material bonds between family members. These choices are not in a vacuum; institutional practices of nation states frame, limit, and contain them. 
Nor do nation-states act entirely freely; their practices are always tightly intertwined with geopolitical regimes and developments (Davydova-Minguet and Pöllänen 2020; Siim 2016; Zechner 2010; Bryceson and Vuorela 2002; Brah 1998).

For the purposes of this study, we have identified four descriptive periods conditioning how transnational familyhood is created and maintained on the Finnish-Russian border. This periodisation follows developments in political atmosphere, international relations between Russia (USSR) and Finland, governance of the border and movement across it. The periods are: (1) the period of confrontation, with a closed and disputed border (1920s-1940s); (2) the Soviet period of friendly cooperation, with a selectively open border (1950s-1980s); (3) the post-Soviet period of a conditionally opened border and migration (1990s-2014); and (4) the post-Crimean period of re-bordering and the securitization of the transnational everyday (2014-). In the following sections we first introduce the historical framework of this article. We then describe the data and methodology used in the article. Chapter 4 contains an analysis of the empirical data, and the final section presents the conclusions.

\section{The Formation of Webs of Transnational Connections from a Historical Perspective}

Transnational connections between Finland and Russia have their roots in the countries' common history. Finland belonged to the Russian Empire between 1809 and 1917. Even before Finland became independent from Russia in 1917, then, it contained a significant Russian minority. The reasons for Russians' settlement in Finland were varied, including business or occupational involvement, membership in the Russian military, being part of the administration of the territory, and family ties. Economic and cultural ties between Finland and Russia were also robust until the Russian Revolution and Finnish independence. For example, many Finns considered St Petersburg the second largest "Finnish city" because of the massive (labour) migration of Finns there (Nevalainen 1999, 2002; Baschmakoff and Leinonen 2001; Shenshin 2008; Leitzinger 2016).

After the Russian Revolution in 1917, the majority of Finns returned to their homeland, a migration supplemented by émigrés from Russia, who after a short stay in Finland continued their journey further into Europe. Though some were temporary migrants, several thousand stayed, contributing significantly to the development of cultural and economic life in Finland. Additionally, several thousand Karelians and Ingrian Finns escaped from Soviet Russia to Finland in this period. The period of post-revolutionary migrations created the oldest layer of transnational Russian-Finnish family relations, which often produced vulnerabilities for their members (Nevalainen 1999, 2002; Baschmakoff and Leinonen 2001; Shenshin 2008; Leitzinger 2016).

The Russian Revolution and Finnish Civil War in 1918 also produced several waves of Finnish migrations to Soviet Russia. Approximately 18,000 "Reds" (the followers of the Left ideology in the Finnish Civil war), defeated in the war, escaped to Russia immediately after 1918 and played a central role in the creation of the Soviet Republic of Karelia. Approximately 30,000 Finns also crossed the border illegally between 1920 and 1930 as "defectors" from Finland, and approximately 6000 moved to Soviet Karelia from the USA and Canada as organized groups of "builders of Socialism" in the 1930s. They became a target of the Stalinist state terror between 1937 and 1938. During the post-revolutionary period, both states considered those who crossed the border in the interwar period as untrustworthy and potentially or immediately dangerous. As a result, maintaining contact with family members and relatives on the other side of the border was difficult or impossible (Golubev and Takala 2014; Lahti-Argutina 2001; Kangaspuro 2000; Sevander and Hertzel 1992).

During the Second World War, Finland and the Soviet Union were involved in two military conflicts, the Winter War (1939-1940) and the Continuation War (1941-1944). These wars entailed the relocation of more than 400,000 Finnish citizens from the annexed territories in the Karelian Isthmus and Ladoga Karelia to Finland. On the other hand, Finland also occupied Soviet Karelia during the Continuation War and accepted a large part of the original Finnish population (Ingrian Finns, more than 60,000) from the Leningrad 
Oblast' between 1943 and 1944. After Finland withdrew from the war against the Soviet Union, the Ingrian Finns had to return to the Soviet Union. Nevertheless, several thousand remained in Finland or escaped to Sweden. Some Karelians who had cooperated with the Finnish military administration during the occupation also moved to Finland, thus producing the next layer of transnational family ties over the border (Nevalainen 1990, 1996; Kinnunen and Kivimäki 2012).

After the wars, Finland found itself in a semi-dependent position as a capitalist country tied to the USSR by the Agreement of Friendship, Cooperation, and Mutual Assistance, signed in 1948. This treaty defined the relations between the countries until 1992, when the Soviet Union ceased to exist. During the post-war period Finland had somewhat restrictive immigration policies, and connections with the Soviet Union especially existed merely at the official level. Despite this, over time tourism between the countries began to grow, and communication between separated relatives became possible, though policed at first by the Soviet authorities. Some Soviet citizens, mostly women, were able to emigrate to Finland in the 1960s through marriage (Leitzinger 2008).

The fall of the Soviet regime and the liberalization of the migration regime in Russia and Finland after the end of the 1980s gradually revitalized old kinships and familyhood, and enabled a new type of emigration to Finland for people mostly from adjacent Russian areas. This emigration involved first people of Finnish descent-descendants of Finns who had fled to Russia in the 1920s and 1930s, and Ingrian Finns, as well as their family members. These "re-migrants" now comprised approximately a third of all post-Soviet migrants in Finland. The second third was composed of those who moved to Finland on the basis of their family ties (Leitzinger 2016; Davydova 2009). Marriage is a gendered migration channel that predominantly involves women. Emigration from Russia today occurs due to family ties, study, entrepreneurship, and work. Currently, estimates of the number of Russian speakers in Finland vary from 80,000 to 100,000, depending on the calculation method. In 2020, 84,190 Russian speakers were officially registered in the country (Statistics Finland 2021).

The atmosphere of the border's expanding openness for migration and transnational connections changed in 2014 with the development of the war in eastern Ukraine and the annexation of Crimea by the Russian Federation. These events, with the European-wide influx of asylum seekers from outside the EU (2015), have led to the proliferation of a discourse of security and danger in Finland. These fears centred on the Russian Federation (and embodied in the figure of Putin), Arab and African asylum seekers, and immigrants in the broad sense. In public discussion and following changes in legislation Russian speakers were conceptualized as a potential danger to Finland through their possible dual citizenship and connections with Russia. Russian citizenship was reconceptualized from a positive resource to an instrument of external and potentially negative influence on the Finnish state. Simultaneously, Russia securitized transnational connections of different levels within the framework of an overall confrontation with the West (see Oivo Forthcoming; Davydova-Minguet and Pöllänen 2017; Oivo and Davydova-Minguet 2019; Oivo et al. 2021).

We use the periodization presented at the beginning of the article as a frame for our analysis; the confrontation period, the cooperative period, the post-Soviet period, and the post-Crimean period (for the full explanation, see above). Though transnational family relations across the Finnish-Russian border have developed in a relatively benevolent atmosphere since the 1990s, the members of transnational families have lived their everyday lives conditioned by different types of precarity. The precarity of transnational family relations caused by the border and its history overlaps with contemporary changes in the geopolitical situation and the emergence of a new "cold war" atmosphere. The FinnishRussian border itself, its practices, and history carries traces of the trauma (see Kurki (2021) which was lived and is present in people's transnational everyday actions. Indeed, in the post-Crimean period, that precarity came to fruition. 


\section{Constructed Typical Stories of Everyday Ethnographies of Transnational Familyhood}

Ethnography is a long-term, empirical, simultaneous and diachronic, localized method of social research practice (Atkinson and Hammersley 2007). Ethnographers are involved, according to Liisa Malkki (2008), in three simultaneously occurring practices: critical theoretical practice; quotidian ethical practice; and improvisational practice. These form the basis for how we undertake and present our research. The result is the construction of "typical stories/typical figures" that in our view convey the essence of transnational familyhood in different historical periods without jeopardizing the informants' privacy. Moreover, our ethnography adheres to the tradition and research lenses of everyday ethnography (Vila 2003; Buzalka and Benč 2007; Passerini et al. 2007; Davydova and Pöllänen 2010). Everyday ethnography refers to a holistic way of doing research and interest in knowledge, which means in our case that we belong to the research field through our family and personal relations, and our ethnographic work has been continuous for a long time, separately and together. We are interested in transnational familyhood and its' affects as versatilely as possible. At the same time our aim is not to build a unisonous representation or extract clearly defined categories from our data, but to be attentive merely to the differences within larger groups than to the differences between single individuals.

We use the concept of everyday in two ways. It is descriptive and contextualizing, and it is a tool of analysis that defines our central themes. The everyday is the context of one's life, constituted by gendered repetitive, mundane, quotidian routines, and practices that are almost invisible and unrecognized, and become visible mainly when they are not actualized (e.g., breastfeeding a baby, doing the laundry, or taking care of the elderly or ill people's medication). As an analytical tool, the concept of everyday is concerned with phenomena that are specifically "unrecognizable", routine, and repetitive (Felski 2000; Jokinen 2005). The transnational perspective concentrates on such everyday practices and social, cultural, and economic ties that span national borders and are practised by non-governmental actors (Khagram and Levitt 2008; Levitt and Schiller 2004). The transnational everyday involves such practices as the intergenerational care that must be organized and realized over the border, involvement in transnational media consumption and production, and maintaining familyhood (see Bryceson and Vuorela 2002; Davydova-Minguet and Pöllänen 2020).

We base this article on our long-term ethnographic work in the border area between Finland and Russia. We have undertaken research in the border area for more than twenty years, together and separately, and have developed a conceptualization of the intersection of bordering and gender in our previous articles (e.g., Davydova and Pöllänen 2010; Davydova-Minguet and Pöllänen 2017). We are especially interested in gendered everyday practices such as transnational care and maintaining family relations which are recognized as typical fields of women's "small" agency (Jokinen 2015; Zechner 2010). For this reason the main body of our data is constituted by the interviews with women. Additionally, women form the majority of Russian-speaking immigrants in Finland and especially in the studied Eastern border region.

The body of our data consists of the field diaries of the long-term (participatory) observations of transnational everyday lives in the border area and dozens of semi-structural and biographical interviews with local Finnish- and Russian-speaking dwellers. We also use ourselves as instruments of research following the ideas of autoethnography (Uotinen 2010; Davydova-Minguet and Pöllänen 2017). However, we based this article largely on the data gathered during our two most recent projects: Perceptions of Russia across Eurasia: Memory, Identity, Conflicts (2015-2017); and Multilayered Borders of Global Security (2017-2019).

Within these two projects, in addition to extensive participatory observations, 21 Russian-speaking informants were interviewed, 16 of which were women. Additionally, two interviews were made in 2020 in our ongoing project on historical memory in Russian-Finnish borderlands. We also used some interviews conducted about two decades ago for our doctoral studies (see Davydova 2009; Pöllänen 2013). In seeing ethnography 
as a long-term improvisational practice (see Malkki 2008), and in terms of data gathering and analysing, we claim that researchers need to open gates in diverse directions and use different materials and methodological tools, as this is the only way to conduct holistic analyses of such a blurred phenomenon as transnational family relations in the tense Finnish-Russian border region. We also set the constructed figures in the context of previous research and memoir literature. We thus aim to place our material in a dialogue with a broader historical context.

Given the multifarious nature of the data, we present our analysis experientially. To approach the data analysis ethnographically in the most attentive way, we have constructed the figures of "Aili" and "Vera", who represent different themes and aspects of the analysed phenomena in different historical periods. These themes are, i.a., the history of migration, everyday life in Finland and in the Soviet Union or/and Russia, transnational family relations and care, as well as transnational media involvement. The figure of "Aili" represents the affective precarity of transnational familyhood in the Soviet era, whereas "Vera" respectively embodies the fragility of transnational familyhood in post-Soviet context. These figures are based on our empirical data, although it should be noted that the actual situations of our individual informants do not consistently fit into these two figures. The situations of some of the informants can be portrayed with the help of both figures, whilst some fit only partly into one of the stories. The stories aim at a clarification of the central elements of transnational familyhood in the Finnish-Russian context diachronically, but analysed from the viewpoint of today.

In summary, we have made a number of methodological choices: first, to construct the figures that represent an analysis of multidimensional, difficult, and precarious situations, instead of using quotations from the interviews; second, to conceal the recognizable interviewees; and third, to co-write the results.

The construction of the imaginary "Aili" and "Vera" also depends on ethical considerations. With the aid of these constructed figures and stories, we can provide our interviewees with the best possible anonymity and privacy protection. Neither "Aili" nor "Vera" are real people, but they are not fictional. The characters are imaginary in the sense that "Aili" and "Vera" do not exist as such; their stories are not told by single individuals but are thematically composed entities from multifarious research materials. We are thus engaged in narrative ethnography. We deal with people's diverse narratives and our autoethnographic notes, and use a narrative approach to the analysis and writing of ethnography (see Heikkilä 2021; Raunola 2010).

\section{Precarious Transnational Familyhood between Two Bordering States}

4.1. The Period of Confrontation, with a Closed and Disputed Border (1920s-1940s), through the Story of "Aili"

The figure of "Aili" represents the experience of transnational familyhood of those Finnish immigrants who arrived in the Soviet Union in the post-revolutionary period. "Aili" was born in North America in a Finnish family at the end of the 1920s. Both her parents had moved there in search of work and prosperity at a time when approximately 350,000 Finns (among about 40 million other Europeans) moved there because of the opportunities afforded by rapid industrialization in the USA and Canada. Despite lacking any education, they easily found employment as workers in primary production and managed to achieve some prosperity, such as owning their own house and car. They were workers, so they were also involved in the socialist movement and other Finnish social activities. They acquired only a poor level of English, using the Finnish language at home and often at work too. In contrast, their daughter "Aili" spoke both Finnish and English (See Sevander and Hertzel 1992; Takala and Golubev 2007).

Aili explains the decision of her parents to move to the Soviet Union in the early 1930 s as the result of the influence of a "Karelian fever", a movement initiated by the Finnish communists in North America and backed by the Communist Party of the Soviet Union, especially its Finnish 
actors. Aili's family decided to move to Soviet Karelia, which was founded and led by communist leaders of Finnish origin in the 1920s, but some of their relatives decided to stay in North America.

Once Aili's family had moved to Soviet Karelia, their everyday life was framed by physical work in primary production in the forestry sector, organized in Finnish work communes by the Soviet state. Aili started to go to school in Finnish. Aili's mother kept in touch with family members who lived in Finland and North America through letter writing. However, such communication and the familyhood it maintained remained fragile, occasional, and vulnerable. Aili's mother knew what kind of news she could report to her sisters and what she could not-for example, the poor material circumstances of their life. With the beginning of the Stalinist terror in 1937 and the death of Aili's mother from a long-term illness, the correspondence ended. Her father was unable to renew the correspondence not only because of the Purges and the fear they generated, but also because of his almost non-existent writing skills. With the beginning of the Continuation War, Aili, her father, and his new wife, a Finnish woman who had been widowed in the Stalinist terror, were evacuated to Siberia, where her father was imprisoned in a labour camp, and Aili worked with her stepmother in a sovkhoz.

In their transnational familyhood the precarity understood as an affect was present in "Aili's" life after she and her parents moved to the Soviet Union. The maintenance of transnational family relations was uncertain, restricted, and even dangerous. In these circumstances people learned to build their social relations primarily in their local, yet ethnic, circle. Those with a shared background and history produced families and familyhoods without the necessity of "blood" relatives. The constructed family relations were thus instrumental in making a harsh life liveable. Yet the capability of maintaining family relations relied on several circumstances. For example, in the case of "Aili" the maintenance of transnational familyhood was restricted by the fact that she was a child and could not maintain the same quality of communication with her relatives as if she were an adult; meanwhile, her father's illiteracy meant he was unable to do so. Moreover, the confrontation that started with the Russian Revolution and Finnish Civil War (1917-1918) and culminated in the Winter and Continuation Wars (1939-1944) were often definitive. Poor relations between Finland and Soviet Russia framed the affective atmosphere and material circumstances of transnational family relations.

\subsection{Post-War Period of "a Mutually Beneficial and Friendly" Cooperation with a Restrictively Open Border (1950s-1980s)}

The Soviet-Finnish Agreement of Friendship, Cooperation, and Mutual Assistance, signed in 1948, defined the post-war relations between Finland and the Soviet Union. The agreement set out the economic cooperation and modes of political rhetoric between the two countries. Stalin's death in 1953 and the decrease of the status of Soviet Karelia from one of 16 Soviet Socialist Republics to an Autonomous Republic within the Russian Soviet Federative Socialist Republic in 1956 indicated a change in the attitudes of the Soviet authorities towards transnational connections. Some Finnish families even managed to return to Finland from the USSR at the time. For many it also meant it was possible to re-establish transnational family relations, which had been interrupted by the period of confrontation and wars.

After the wartime evacuation, Aili's family returned to Soviet Karelia and continued their work in the forestry sector. Her aunt, then living in Australia, initiated the first contact. Gradually, Aili's family re-established correspondence with relatives in Finland, and the first meetings with them happened in Leningrad through organized Finnish tourism, which had been possible since the end of the 1950s.

Meanwhile, Aili married a man from the same background: he had been born in Finland and had come to Soviet Russia as a child with his parents. He also had relatives in Finland, and after the re-establishment of connections with his relatives and the relaxation of the border and travel regime in the USSR in the late 1960s, they had an opportunity to travel to Finland. This trip was the result of a very laborious and complex process, entailing an official invitation from Finland and passports and permission to travel from the Soviet authorities. Although the invitation included 
their children, the state eventually permitted only Aili and her husband to travel to Finland. The trip showed that despite all the interruptions, the family relationships had survived and could be revived. Aili and her husband toured Finland, meeting not only their blood relatives but the siblings of her stepmother. Aili felt she and her husband fit in with their Finnish kin, because although life under Stalin's rule had been harsh, they had been lucky: both had lived with their families who had survived the state terror. Most fortunately, unlike many other children of Finnish origin, they had not been orphaned; those who found themselves in the orphanages forgot their Finnish, which they had spoken better than Russian.

In addition to the eagerness to maintain social relations with relatives, the trips to Finland were also instrumental for the purchase of goods impossible or difficult to obtain in the USSR because of the shortages produced by the socialist economy.

The precarious familyhood recreated/produced after the long break manifested itself in diverse ways. Without "natural" everyday connections and interaction between family members and kin, other "makers of familyhood" emerged in interviews, including shared languages and dialects, and the notion of biological roots. In cases where adult members of the family perished in Stalin's purges, and their children were raised in Soviet orphanages and therefore did not speak Finnish, one tool always proved shared kinship - a similarity in appearance. When members of the family met for the first time and lacked a common language, they highlighted similarity in appearance in their accounts.

Yet the maintenance of contacts with Finnish relatives remained difficult and heavily controlled by the Soviet authorities, and a sense of being controlled, suspected, and restricted accompanied the construction of familyhood, producing affective precarity in transnational family relations.

\subsection{Post-Soviet Period of a Conditionally Open Border and Migration (1990s-2014)}

In the post-Soviet period three processes enabled an explosion in the formation of transnational families, namely the development of cross-border tourism and contacts, the opening of new checkpoints, and changes in migration and border regimes. These enabled massive immigration of former Soviet citizens to Finland. Nevertheless, crossing the border has always required a valid passport with a visa or residence permit. The border crossing regime had been liberalizing since the beginning of the 1990s, and in the 2010s the two countries even discussed allowing a visa-free regime between Finland and Russia. Unfortunately, this stopped with the annexation of Crimea in 2014.

The first major change was the development of tourism and border crossings between Finland and Russia. These were intertwined with the opening of new checkpoints on the previously almost closed border. Tourism between Finland and the Soviet Union was already growing in the late 1980s, but it remained highly controlled by the Soviet state. Until the end of the 1980s, only private individuals at the southern checkpoints of Vaalimaa (by train) and Nuijamaa (mostly by bus) could cross the Finnish-Russian border. Gradually, new checkpoints started to open. Crossings at these checkpoints first became possible with special permission at the end of the 1980s for those participating in emerging official and business contacts. Later, these crossing points opened for organized tourism. Former dwellers of formerly Finnish territories ceded in the war were the first to travel extensively in the adjacent Russian areas (Fingerroos and Häyrynen 2012; Fingerroos and Loipponen 2007). The opening of the border was of great interest to the border dwellers on both sides, and after a wave of "nostalgic tourism," a more mundane shopping tourism became the main reason for border crossings. For example, after the Niirala-Värtsilä crossing point, at a gate between Russian and Finnish Karelia, opened for the general public in 1992, the number of border crossings grew steadily until the outbreak of the crisis in EU-Russia relations in 2014. In 2012 there were almost 13 million crossings of the Finnish-Russian border at 11 checkpoints, with 1.6 million at Niirala-Värtsilä (The Finnish Border Guard 2017).

A second transformation was the contemporary immigration of Russian speakers to Finland. This started in 1990 and occurred through several immigration channels such as the re-migration of people of Finnish origin (the "Aili" case), marriage (the "Vera" case), 
study, and work (see e.g., Davydova 2009; Pöllänen 2013). Thus, some Russian speakers migrated to Finland with their nuclear families, while others made families in Finland. Marriage migration from Russia to Finland was and is a gendered phenomenon: Russian women usually contract marriages with Finnish men (Pöllänen 2013).

Regionally, Russian speakers primarily live in the capital area and the other big cities; more than $40 \%$ of Russian speakers live in the capital region. Yet Russian speakers are also concentrated in the rural border areas of Finland. Indeed, in Eastern Finnish rural border areas the presence of Russian speakers is clear both in statistical figures and in everyday reality. Russian speakers are even more visible and significant groups of the immigrant population. For example, in the small rural border municipality of Tohmajärvi, Russian speakers comprise $4 \%$ of the population, whereas in Helsinki their share is $2.8 \%$ of the total population (Varjonen et al. 2017, p. 12). Significantly, Russian speakers merge into the larger foreign-born population in the capital area, whereas in Tohmajärvi, they represent the great majority of immigrants. Thus, Russian speakers in the Eastern rural areas of Finland offer a portrait of general immigration.

Aili and her husband moved to a municipal centre in Finnish Karelia a few years after their adult daughter moved there with her family in the 1990s. They obtained a residence permit easily because of their Finnish descent and their parents' former Finnish citizenship. Their daughter was among the first "re-migrants" to move to Finland from Russian Karelia. She and her parents faced a relatively easy process because of their native Finnish language. Aili's daughter was relieved when she got her parents close to her in Finland; indeed, she took care of the massive paperwork their re-migration required. Her efforts meant that the burden of transnational care became local.

In the case of Russian speakers' families, it is important to consider how the family itself is defined. Whereas Finnish family culture and welfare politics are framed by the nuclear family model (Yesilova 2009; Fingerroos et al. 2016), the Russian post-Soviet family culture and politics are based on the extended family model (Rotkirch 2000; Pöllänen 2013; see also Assmuth et al. 2018). In the Finnish welfare state benefits and services are organized on an individual and egalitarian basis, which means adults' only intergenerational (care) obligations are to their children. In the Russian extended family model adults have intergenerational care responsibilities and obligations also to their elderly parents. In general, this means that in the Russian extended family model adult children are morally and legally obliged to take care of their elderly parents (See Davydova-Minguet and Pöllänen 2020). Finnish immigration policy, as part of welfare state policy, is built on the concept of the nuclear family and does not recognize intergenerational family relations in the upward direction. These two models of care affected extended transnational families.

The majority of Finland's Russian speakers originate from the adjacent areas of Russia. Typically, Russian speakers migrate to Finland within relatively short distances of a few hundred kilometres spanning the state border. The transnational life of Russian speakers involves everyday border crossings through the Niirala-Värtsilä checkpoint. "Vera" represents a typical Russian-speaking immigrant woman who has migrated to Finland from nearby Russian territory.

Vera moved from the Russian town of Sortavala to the Finnish Tohmajärvi municipality. Her mother still lives in Sortavala. Sortavala is $80 \mathrm{~km}$ from Tohmajärvi, and the Niirala-Värtsilä checkpoint is $20 \mathrm{~km}$ from her home. Vera moved to Tohmajärvi to be with her Finnish husband Ville, a local retired farmer and slightly older than she. Vera and Ville have children from previous marriages, and they also have children in common.

Vera has several care duties in Finland, Russia, and beyond. Her mother and disabled brother live in Sortavala, and Vera cares for them from a distance. Vera also cares for her parents-in-law in Tohmajärvi and her grandchild, who lives in London. Vera works as a shop assistant in Tohmajärvi and sometimes in mixed jobs (such as interpreting and cleaning) in the neighbouring municipality Kitee. Although she does not have a permanent contract, she has a position in the precarious Finnish labour market. Several circumstances frame her life: the unstable income from her precarious job and Ville's pension, her burdens of transnational care, and difficulties of the Niirala-Värtsilä checkpoint. 
"Aili's" and "Vera's" everyday lives and both their transnational families experienced "affective precarity" since they emigrated to Finland. The border between Finland and Russia, even after its opening at the beginning of the 90s, remained highly controlled, and this defined everyday interaction across it, for example, for transnational care. The border crossing process has always been unpredictable, time consuming, and arbitrary. Border crossing queues, changing regulations, and the demands of paperwork before crossing the border between two "blocks" was an everyday reality especially for those, who, like "Vera", had transnational care obligations. The other source of a precarity in "Vera's" case was the instability of the labour market position in Finland. Additionally, as we analysed in our previous studies, the economic disparity between the "West" and "Russia" and the post-Soviet changes in gender orders especially affected the position of Russian women. Femininity became a resource that made moving to the "West" possible; yet it became ethnicized and sexualized (Davydova and Pöllänen 2010). Both "Aili" and "Vera" had everyday lives marked by constant border crossings, which in turn defined them in national and ethnic terms.

\subsection{The Fragility of Transnational Families in the Post-Crimean Rebordering Period}

Since the collapse of the Soviet Union, the most significant change in the geopolitical context which has influenced the everyday lives of the border areas has been the international conflict between Russia and the EU caused by the 2014 Russian annexation of Crimea. The post-Crimean geopolitical situation manifested in two ways: the decrease in border crossings (from 12.9 million in 2013 to 9 million 2017, (The Finnish Border Guard 2017)); and the decline in Russian tourism to Finland, caused partly by the devaluation of the Russian rouble and partly by the introduction of new regulations and restrictions on both sides of the border. For translocal families and people of Russian origin, this entails ever-increasing precarity and insecurity in maintaining their family relations and transnational care. The geopolitical change associated with Russia's annexation of Crimea and the beginning of the "new Cold War" in the relations between Russia and the EU is tangible and visible in the border areas of Finland.

The most concrete consequence of the tense relations between Russia and the "West" for Russian-speaking immigrants in Finland has been the changes in the laws and regulations concerning dual citizenship. Finnish legislation has allowed dual citizenship since 2003. People with Russian and Finnish citizenship now form the largest group among all dual citizens (more than 33,000 of more than 137,000 in 2019, (Statistics Finland 2019)). After the annexation of Crimea, the Finnish Ministry of Defence started to draft a law to restrict the possibilities of people with dual citizenship or other links to foreign states to serve in or to get an education for security-related public offices. Simultaneously, the Russian government adopted several restrictions for people with residence permits or citizenships of other states. Russian speakers in Finland were overwhelmed by these developments, feeling the Finnish restrictions especially targeted them. These political moves created an atmosphere of distrust and insecurity (See Oivo Forthcoming; Oivo and Davydova-Minguet 2019). For the members of transnational families this period has meant uncertainty and anxiety about the future of the border crossing procedure and their possibilities of continuing previously developed care practices.

Vera is worried and nervous about her contemporary and future situation as a dual citizen in Finland. One of her main concerns is whether her dual citizenship will affect her children's opportunities in Finland. What if her daughter wants to be a police officer or start a military career? Is it enough that her daughter herself has only Finnish citizenship, or does Vera's dual citizenship also affect her children? She has no answers to these questions, but there are many rumours among Russian speakers. She is also very worried about her disabled brother, who lives in the countryside near Sortavala: will she be able to cross the border as frequently as before to bear the main care responsibility for him?

Vera crosses the border every week. Almost every weekend she drives to Sortavala to meet and take care of her mother and disabled brother. Ville accompanies her occasionally. Although the border 
crossing has been an everyday routine for Vera for more than two decades, she describes it as fragile and unpredictable. This feeling has peaked since the Crimean crisis, but Vera has no options: she must simply cross the border because of her family relations and care responsibilities. She dreams of a family reunification on the Finnish side, but this is impossible because of the immigration regulations, which recognize only the nuclear family as grounds for obtaining a residence permit.

The conflict between Russia and Ukraine has also had an influence which has not materialized in legislation but continues to affect relations between people. Among Russian speakers, it has created a sharp polarization of opinions tightly intertwined with media consumption patterns. The overall mediatization and polarization of societies has strengthened through this and subsequent conflicts (Oivo et al. 2021).

Russian speakers use national and transnational media heavily, and the Crimean conflict has activated various reactions and changes in relations. Some uses have become even more attached to using media; others have chosen their side (pro- or anti-Russian); and some have limited media use to relaxation and entertainment (see Sotkasiira 2017). The print media and the TV news produced in Russian in Finland reach Russian speakers poorly, but social media affords fertile grounds for gaining and producing information (see Davydova-Minguet 2017). Social media is an important tool to maintain transnational relationships, and involvement in social media also curates media content consumed and discussed in echo chambers that have become transnational. At the same time, the consumption and production of the media have become even more segmented, and Russian speakers' echo chambers revolve around the themes of the war in Ukraine, Russia's shaky role in world politics, the "influx of refugees" and other racialized migrants to Finland and Europe, cases of child custody, and the sense of social precarity. The mediatized polarization affects relations between relatives, family members, friends, and acquaintances. Some of these relations have been interrupted. In some cases, people have developed modes of conversation that consciously exclude heated themes to preserve social connections.

Vera follows the Russian media, and she loves Russian political talk shows. She is at odds with her sister who lives in Ukraine and prefers not to speak about the Russian-Ukrainian conflict with her and other Russian speakers. With her Russian-speaking acquaintances she has developed a new "post-Crimean" way of communicating that avoids conversations about politics and society. In her opinion most Finns are affected by the propaganda of the Finnish media, and they do not understand the historical background of the Crimean situation. She feels that the fear of Russia in Finland is unnecessary. Yet she sometimes wonders if it is justified.

Vera actively participates in social media discussions. She is involved in the networks of Russian speakers living in Finland. Some news from the Finnish tabloid press or alternative media is circulated there, and they create moral panic and feelings of insecurity. The themes that gain most attention there are issues of child welfare-custody cases involving children of Russian mothers in Finland and beyond, and in recent years the Ukrainian situation and the increased number of asylum seekers and refugees in Finland. Vera is afraid of these new migrants, and she speaks willingly about the "migration crisis" as a common threat to Europe.

The current period of intensifying conflict between Russia and the "West" has had concrete juridical or material consequences. In addition to changes in the legislation of both countries which has securitized transnational connections, it has also affected the ethnicized labour markets where many Russian speakers previously found job opportunities. With the decrease in Russian and Finnish tourism, translation and sales services are in less demand, and some Russian speakers have experienced shortfalls in their incomes that have affected their ability to support their transnational families financially. Yet the conflict has also had many subtler effects on social relations, both transnationally and locally.

\section{Conclusions: The Precarious Transnational Family}

In our view, the precarity produced by families' transnationality is an affective condition which has institutional and personal dimensions as well as its own history. In this article we have considered the precarity of the transnational family as an affect in the 
context of the tightly interconnected yet tense neighbourhood of Finland and Russia. The diachronic approach to precarity in transnational family relations helps us understand its historical dimensions and the influence of state and societal structures on it. Since the formation of the state border between Finland and Russia, transnational family relations have followed a circular trajectory, from pre-revolutionary acceptance to almost total prohibition during the period of confrontation and Stalin's rule, and from gradual re-awakening in the late Soviet period to the acceptance of a transnational extended family in the post-Soviet period.

The post-Crimean conflictual international atmosphere has reawakened tensions and memories of the ruptures and violence that have affected and can still affect transnational family ties. To return to the conceptualization of precarity to which we referred at the beginning of the article (Jokinen 2020), the precarity of transnational familyhood as an eternal condition of a potentiality that "something unexpected, unpleasant, uncontrollable may happen" is present in narratives about the experiences of maintaining family ties over the Finnish-Russian border. The changes, endeavours, and events that happen at the level of state actors and structures are indeed "a lease that is not in your own pocket" (Jokinen 2020).

In conclusion, the lived everyday and maintenance of the transnational familyhood of Russian-speaking immigrants in Finland have become more precarious and ambivalent in the post-Crimean reality. Many view Russia as a source of increased danger in Finland, and those who have connections with Russia, and above all those who possess Russian citizenship, have become an object of suspicion. Simultaneously, throughout the 2010s Russia has securitized its citizens' and other Russian speakers' transnational ties, presenting them as a threat to its national security and demanding that people expose their transnational connections to Russian authorities. Meanwhile restricting some rights of people with transnational affiliations and thus further loading the transnational space with emotions and affects. The "West-Russia" affective division is present at the family level, for example in family members' differing positionings towards Russian and Finnish media, the conflict in Ukraine, Russian-EU relations, and historical memory (Oivo and Davydova-Minguet 2019; Sotkasiira 2017).

Transnational familyhood in the diachronic perspective demonstrates that the ways family ties are maintained has expanded dramatically. In the periods of a closed border and conflictual geopolitical situations, transnational familyhood survived through letters and personal meetings that states could thoroughly control. In contrast, in the time of open borders, and with the development of transport and communication technologies, the autonomy of transnational families has expanded. However, the states have retained the authority over the border crossing and thus over the possibilities to be physically in touch. Meanwhile, states which are seen to be suffering from a deficit of democracy have gained more means to control information and communication spaces (Polyakova and Meserole 2019; Pomerantsev 2019). Although how states control family has changed, the essence of the role of the states remains and forms the affect of precarity, filling it with emotions such as unpredictability, ambivalence, uncertainty, and fear, but at the same time hope and openness.

Author Contributions: Conceptualization, O.D.-M. and P.P.; methodology, O.D.-M. and P.P.; software, O.D.-M. and P.P.; validation, O.D.-M. and P.P.; formal analysis, O.D.-M. and P.P.; investigation, O.D.-M. and P.P.; resources, O.D.-M. and P.P.; data curation, O.D.-M. and P.P.; writing-original draft preparation, O.D.-M. and P.P.; writing—review and editing, O.D.-M. and P.P.; visualization, O.D.-M. and P.P.; funding acquisition, O.D.-M. and P.P. All authors have read and agreed to the published version of the manuscript.

Funding: This research received no external funding. The data for this article were acquired within the project Perceptions of Russia across Eurasia: Memory, Identity, Conflicts (Academy of Finland's decision number 294347). 
Institutional Review Board Statement: Ethical review and approval were waived for this study, due to the longitudinal character of the ethnographic study and adherence to the standards of the Finnish National Board on Research Integrity TENK.

Informed Consent Statement: Informed consent was obtained from all subjects involved in the study.

Data Availability Statement: The data are stored at the UEF and are not available to external parties due to their sensitive character.

Conflicts of Interest: The authors declare no conflict of interest. The funders had no role in the design of the study; in the collection, analyses, or interpretation of data; in the writing of the manuscript, or in the decision to publish the results.

\section{References}

Adkins, Lisa, and Eeva Jokinen. 2008. Introduction: Gender, Living and Labour in the Fourth Shift. NORA-Nordic Journal of Feminist and Gender Research 16: 138-49. [CrossRef]

Ahmed, Sara. 2004. The Cultural Politics of Emotion. Edinburgh: University Press.

Åkerblad, Leena. 2014. Epävarmuuden Tuolla Puolen: Muuttuvat Työmarkkinat ja Prekaari Toimijuus. Joensuu: Itä-Suomen yliopisto.

Assmuth, Laura, Marina Hakkarainen, Aija Lulle, and Pihla Maria Siim. 2018. Translocal Childhoods and Family Mobility in East and North Europe. London: Palgrave Macmillan.

Atkinson, Paul, and Martyn Hammersley. 2007. Ethnography: Principles in Practice. London: Routledge.

Baschmakoff, Natalia, and Marja Leinonen. 2001. Russian Life in Finland 1917-1939: A Local and Oral History. Helsinki: Studia Slavica Filandensia.

Berlant, Lauren. 2011. Cruel Optimism. Durham: Duke University Press.

Brah, Avtar. 1998. Cartographies of Diaspora. Contesting Identities. London and New York: Routledge.

Brambilla, Chiara. 2015. Exploring the Critical Potential of the Borderscapes Concept. Geopolitics 20: 14-34. [CrossRef]

Bryceson, Deborah, and Ulla Vuorela, eds. 2002. The Transnational Family. New European Frontiers and Global Networks. Oxford: Berg.

Buzalka, Juraj, and Vladimir Benč. 2007. EU Border Monitoring: Slovak—Ukrainian Border Vyšné Nemecké/Uzhgorod and Vel'ké Slemence/Mali Selmenci. Bratislava and Prešov: The Slovak Foreign Policy Association.

Davydova, Olga, and Pirjo Pöllänen. 2010. Gender on the Finnish-Russian Border: National, Ethnosexual and Bodily Perspective. In Ethnosexual Processes. Realities, Stereotypes and Narratives. Edited by Joni Virkkunen, Pirjo Uimonen and Olga Davydova. Helsinki: Kikimora Publications, pp. 18-35.

Davydova, Olga. 2009. Suomalaisena, Venäläisenä ja Kolmantena. Etnisyysdiskursseja Transnationaalissa Tilassa. Joensuu: Joensuun yliopisto.

Davydova-Minguet, Olga, and Pirjo Pöllänen. 2017. Gendered Everyday Bordering: An Ethnographic Case Study on the Border between Finland and Russia. In Women and Borders: Refugees, Migrants and Communities. Edited by Seema Shekhawat and Emanuela C. Del Re. London: I.B. Tauris \& Co Ltd., pp. 175-96.

Davydova-Minguet, Olga, and Pirjo Pöllänen. 2020. Everyday transnational Russian-Finnish family relations in a Finnish rural border area. In Family Life in Transition. Borders, Transnational Mobility, and Welfare Society in Nordic Countries. Edited by Johanna Hiitola, Kati Turtiainen, Sabine Gruber and Marja Tiilikainen. London and New York: Routledge, pp. 107-17. [CrossRef]

Davydova-Minguet, Olga. 2017. Suomen venäjänkielinen media ja monietninen julkisuus. Idäntutkimus 3: 3-19.

Felski, Rita. 2000. Doing Time: Feminist Theory and Postmodern Culture. New York: NYU Press.

Fingerroos, Outi, and Jaana Loipponen, eds. 2007. Nykytulkintojen Karjala. Jyväskylä: Jyväskylän yliopisto.

Fingerroos, Outi, and Maunu Häyrynen, eds. 2012. Takaisin Karjalaan. Helsinki: SKS.

Fingerroos, Outi, Anna-Maria Tapaninen, and Marja Tiilikainen. 2016. Kurittomat perheet: Parheen käsitteen monet muodot historiassa ja eri kulttuureissa. In Perheenyhdistäminen. Kuka saa perheen Suomeen, Kuka ei ja Miksi? Edited by Outi Fingerroos, Anna-Maria Tapaninen and Marja Tiilikainen. Tampere: Vastapaino, pp. 21-41.

Golubev, Aleksei, and Irina Takala. 2014. The Search for a Socialist El Dorado: Finnish Immigration to Soviet Karelia from the United States and Canada in the 1930s. East Lansing: Michigan State University Press.

Heikkilä, Eino. 2021. Etnografian kerronnallisuus ja aika. Elore 28: 1. [CrossRef]

Hyvönen, Heli. 2007. "Koti on Suomessa mutta kotimaa on Viro". Suomessa asuvien virolaisäitien transnationaaliset sosiaaliset tilat. In Maahanmuuttajanaiset: Kotoutuminen, Perhe ja työ. Edited by Tuomas Martikainen and Marja Tiilikainen. Helsinki: Väestöliitto, pp. 190-217.

Jokinen, Eeva, and Juhana Venäläinen, eds. 2015. Prekarisaatio ja Affekti. Jyväskylä: Jyväskylän yliopisto.

Jokinen, Eeva. 2005. Aikuisten arki. Helsinki: Gaudeamus.

Jokinen, Eeva. 2015. Precarious everyday agency. European Journal of Cultural Studies 19: 1. [CrossRef]

Jokinen, Eeva. 2020. Ilmassa prekaarisuuden tuntua. Paper presented at the Converence Työelämän tutkimuspäivät 12 October 2020. Available online: Availableonline:https:/ / events.tuni.fi/uploads/2020/12/1c9c4024-eeva-jokinen-puhe.pdf (accessed on 22 June 2021).

Kangaspuro, Markku. 2000. Neuvosto-Karjalan Taistelu Itsehallinnosta. Nationalismi ja Suomalaiset Punaiset Neuvostoliiton Vallankäytössä 1920-1939. Helsinki: SKS.

Khagram, Sanjeev, and Peggy Levitt, eds. 2008. The Transnational Studies Reader: Intersections and Innovations. London: Routledge. 
Kinnunen, Tiina, and Ville Kivimäki, eds. 2012. Finland in World War II: History, Memory, Interpretations. Leiden: Brill.

Kurki, Tuulikki. 2021. From heroism to grotesque: The invisibility of border-related trauma narratives in the Finnish-Russian borderlands. In Border Images, Border Narratives: The Political Aesthetics of Boundaries and Crossings. Edited by Johan Schimanski and Jopi Nyman. Manchester: Manchester University Press, pp. 105-26.

Lahti-Argutina, Eila. 2001. Olimme Joukko Vieras Vaan: Venäjänsuomalaiset Vainonuhrit Neuvostoliitossa 1930-Luvun Alusta 1950-Luvun Alkuun. Turku: Siirtolaisuusinstituutti.

Leitzinger, Antero. 2008. Ulkomaalaispolitiikka Suomessa 1812-1972. Helsinki: East-West Books.

Leitzinger, Antero. 2016. Venäläisten muutto Suomeen kautta aikojen. In Venäjänkieliset Suomessa-Huomisen Suomalaiset. Edited by Arno Tanner and Ismo Söderling. Turku: Siirtolaisuusinstituutti, pp. 41-75.

Levitt, Peggy, and Nina Glick Schiller. 2004. Conceptualizing Simultaneity: A Transnational Social Field Perspective on Society. The International Migration Review 38: 1002-39. [CrossRef]

Malkki, Liisa. 2008. Tradition and Improvisation in Ethnographic Field Research. In Improvising Theory: Process and Temporality in Ethnographic Fieldwork. Edited by Allaine Cerwonka and Liisa Malkki. Chicago: University of Chicago Press, pp. 162-88. [CrossRef]

Nevalainen, Pekka. 1990. Inkeriläinen Siirtoväki Suomessa 1940-Luvulla. Helsinki: Otava.

Nevalainen, Pekka. 1996. Rautaa Inkerin Rajoilla: Inkerin Kansalliset Kamppailut ja Suomi 1918-1920. Historiallisia tutkimuksia 195. Helsinki: SKS.

Nevalainen, Pekka. 1999. Viskoi kuin Luoja Kerjäläistä: Venäjän Pakolaiset Suomessa 1917-1939. Suomalaisen Kirjallisuuden Seuran Toimituksia 742. Helsinki: SKS.

Nevalainen, Pekka. 2002. Punaisen Myrskyn Suomalaiset: Suomalaisten Paot ja Paluumuutot idästä 1917-1939. Suomalaisen Kirjallisuuden Seuran Toimituksia 867. Helsinki: SKS.

Oivo, Teemu, and Olga Davydova-Minguet. 2019. Kaksoiskansalaisuuden turvallistaminen ja Suomen venäjänkieliset. Idäntutkimus 26: 59-77. [CrossRef]

Oivo, Teemu, Olga Davydova-Minguet, and Pirjo Pöllänen. 2021. Puun ja kuoren välissä. Ristiriitaiset lojaliteettivaatimukset Suomen venäjänkielisten ylirajaisessa arjessa. In Arjen Turvallisuus ja Muuttoliikkeet. Edited by Laura Assmuth, Ville-Samuli Haverinen, Eeva-Kaisa Prokkola, Pirjo Pöllänen, Anni Rannikko and Tiina Sotkasiira. Tietolipas 269. Helsinki: SKS, pp. 60-90.

Oivo, Teemu. Forthcoming. Exclusive citizenship-membership? Meanings of Finnish-Russian bonds and belonging. Laboratorium.

Paasi, Anssi. 1998. Boundaries as Social Processes: Territoriality in the World of Flows. Geopolitics 3: 69-88. [CrossRef]

Papadopoulos, Dimitris, Niamh Stephenson, and Vassilis Tsianos. 2008. Escape Routes. Control and Subversion in the Twenty-First Century. London: Pluto Press.

Passerini, Luisa, Dawn Lyon, Enrica Capussotti, and Ioanna Lalioutou, eds. 2007. Women Migrants from East to West. Gender, Mobility and Belonging in Contemporary Europe. New York and Oxford: Bergham Books.

Pöllänen, Pirjo, and Olga Davydova-Minguet. 2017. Welfare, Work and Migration from a Gender Perspective: Back to “Family Settings"? Nordic Journal of Migration Research 7: 205-13. [CrossRef]

Pöllänen, Pirjo. 2013. Hoivan Rajat_Venäläiset Maahanmuuttajanaiset ja Ylirajainen Perhehoiva. Helsinki: Väestöliitto.

Polyakova, Alina, and Chirs Meserole. 2019. Exporting Digital Authoritarianism: The Russian and Chinese Models. Available online: https://www.brookings.edu/wp-content/uploads/2019/08/FP_20190827_digital_authoritarianism_polyakova_meserole. pdf (accessed on 22 June 2021).

Pomerantsev, Peter. 2019. This Is Not Propaganda. Adventures in the War Against Reality. London: Faber \& Faber.

Raunola, Ilona. 2010. Osallisuus ja dialoginen paikantuminen etnografisessa kenttätyössä. In Vaeltavat Metodit. Edited by Jyki Pöysä, Helmi Järviluoma and Sinikka Vakimo. Joensuu: Suomen Kansantietouden Tutkijain Seura, pp. 285-314.

Rigo, Enrica. 2009. Rajojen Eurooppa. Helsinki: Like.

Rotkirch, Anna. 2000. The Man Question. Loves and Lives in Late 20th Century Russia. Helsinki: University of Helsinki, Department of Social Policy.

Saarinen, Aino. 2007. Venäläiset Maahanmuuttajanaiset "Naisystävällisessä" Pohjolassa: Kansalaisuus ja Stigmati-Soinut Identiteetti. Edited by Tuomas Martikainen and Marja Tiilikainen. Helsinki: Väestöliitto, pp. 125-46.

Sevander, Mayme, and Laurie Hertzel. 1992. They Took My Father: A Story of Idealism and Betrayal. Duluth: Pfeifer-Hamilton.

Shenshin, Veronica. 2008. Venäläiset ja Venäläinen Kulttuuri Suomessa. Kulttuurihistoriallinen Katsaus Suomen Venäläisväestön Vaiheista Autonomian Ajoilta Nykypäiviin. Helsinki: Aleksanteri-instituutti.

Siim, Pihla Maria. 2016. Everyday Practices of Translocal Families: Estonian Children and a Sense of Being-in-Place. Ethnologia Fennica 43: 12-27. Available online: https:/ /journal.fi/ethnolfenn/article/view/65632 (accessed on 22 June 2021).

Sotkasiira, Tiina. 2017. Suomen venäjänkieliset mediayleisönä. Idäntutkimus 3: 20-35.

Statistics Finland. 2019. Available online: https:/ /www.stat.fi/tup/maahanmuutto/suomen-kansalaisuuden-saaneet.html (accessed on 22 June 2021).

Statistics Finland. 2021. Available online: https:/ / www.tilastokeskus.fi/tup/suoluk/suoluk_vaesto.html (accessed on 22 June 2021).

Takala, Irina, and Aleksei Golubev, eds. 2007. Ustnaia Istoriia v Karelii. Sb. Nauch. st. i Istorchnikov. Vyp. II. Severoamerikanskie Finny v Sovetskoi Karelii 1930-h Godov. Petrozavodsk: Izd-vo PetrGU.

The Finnish Border Guard. 2017. Available online: https:/ / www.raja.fi/download/72227_rajanylitystilasto_2017.pdf?07f93d44a38dd5 88 (accessed on 22 June 2021). 
Tiaynen, Tatiana. 2013. Babushka in Flux: Grandmothers and Family-Making between Russian Karelia and Finland. Tampere: Tampere University Press, Available online: http:/ / urn.fi/URN:ISBN:978-951-44-9147-4 (accessed on 22 September 2021).

Uotinen, Johanna. 2010. Aistimuksellisuus, autoetnografia ja ruumiillinen tietäminen. Elore 17: 1. Available online: http://www.elore. fi/arkisto/1_10/katsart_uotinen_1_10.pdf (accessed on 22 June 2021). [CrossRef]

Varjonen, Sirkka, Aleksandr Zamiatin, and Marina Rinas. 2017. Russians in Finland: Here and Now. Statistics, Surveys, Organizational Field. Helsinki: Cultura Foundation.

Vila, Pablo, ed. 2003. Ethnography at the Border. Minneapolis and London: University of Minnesota Press.

Yesilova, Katja. 2009. Ydinperheen Politiikka. Helsinki: Gaudeamus.

Zechner, Minna. 2006. Hoivan paikat transnationaalisissa perheissä. In Ylirajainen kulttuuri. Etnisyys Suomessa 2000-Luvulla. Edited by Tuomas Martikainen. Helsinki: SKS, pp. 83-103.

Zechner, Minna. 2008. Care of older persons in transnational settings. Journal of Aging Studies 22: 32-44. [CrossRef]

Zechner, Minna. 2010. Informaali Hoiva Sosiaalipoliittisessa Kontekstissa. Tampere: Tampereen yliopisto. 